\title{
Mercury Speciation in Natural and Mining-Related Systems
}

\author{
Maria A. Gustaytis*a, \\ Irina N. Myagkaya ${ }^{a}$, Victor I. Malova, \\ Elena V. Lazareva ${ }^{a}$ and Olga V. Shuvaeva ${ }^{b}$ \\ ${ }^{a}$ V.S. Sobolev Geology and Mineralogy SB RAS \\ Novosibirsk, Russian Federation \\ ${ }^{b}$ A.V. Nikolaev Institute of Inorganic Chemistry SB RAS \\ Novosibirsk, Russian Federation
}

Received 12.04.2021, received in revised form 06.05.2021, accepted 06.06.2021

\begin{abstract}
Mercury speciation and the composition of mercury phases in natural and mining-related environments is studied by the thermal release analysis combined with electrothermal atomic absorption spectroscopy (TA-ET-AAS), as well as scanning electron microscopy with energy-dispersive X-ray microanalysis (SEM-EDS). The analyses are applied to laboratory-made samples bearing mercury selenide and to field samples from sites known for relatively high natural or industrially induced $\mathrm{Hg}$ background. They are, namely, material from the dispersion train of the Ursk sulfide tailings (Ursk Village, Kemerovo region) and debris precipitated from snow sampled in the Kurai mercury zone (Aktash Village, Gorny Altai).

The TA-ET-AAS method works well in discrimination and identification of $\mathrm{Hg}$ sulfide and $\mathrm{Hg}$ selenide provided that the samples contain sufficient amounts of both compounds, but the sum $\mathrm{HgS}+\mathrm{HgSe}$ can be determined at any contents of the two compounds.

The presence of both mercury sulfide and mercury selenide in the samples has been confirmed by SEM-EDS microanalysis. The temperature ranges for the mercury species $\left(\mathrm{Hg}^{2+} ; \mathrm{HgS}+\mathrm{HgSe}\right.$ mixture; mercury bound with organic matter $(\mathrm{Hg}-\mathrm{OM})$, including $\left.\mathrm{CH}_{3} \mathrm{Hg}^{+}\right)$are identical in the laboratory and field samples. Therefore, the suggested approach can ensure fast and reliable detection of $\mathrm{Hg}$ phases in rocks exposed to supergene alteration.
\end{abstract}

Keywords: mercury speciation, combined TA-ET-AAS method, scanning electron microscopy, secondary Hg minerals.

(C) Siberian Federal University. All rights reserved

This work is licensed under a Creative Commons Attribution-NonCommercial 4.0 International License (CC BY-NC 4.0).

* Corresponding author E-mail address: gustaitis@igm.nsc.ru 


\title{
Изучение состава минералов $\mathrm{Hg}$ в природно-техногенных системах
}

\author{
М.А. Густайтис ${ }^{\mathrm{a}}$, И.Н. Мягкая \\ В.И. Малов ${ }^{a}$ Е. В. Лазарева ${ }^{a}$, О. В. Шуваева ${ }^{\sigma}$ \\ ${ }^{a}$ Институт геологии и минералогии \\ им. В. С. Соболева СО РАН \\ Российская Федерация, Новосибирск \\ ${ }^{6}$ Институт неорганической химии \\ им. А. В. Николаева СО РАН \\ Российская Федераџия, Новосибирск
}

\begin{abstract}
Аннотация. Для изучения состава минералов ртути в природных и техногенных объектах предложен подход, сочетающий метод термического анализа с электротермическим атомноабсорбционным детектированием (ТА-ЭТА-ААС) и сканирующую электронную микроскопию (СЭМ ЭДС). Исследования проводили с использованием модельного образца, содержащего селенид ртути, а также образцов, отобранных на объектах, характеризующихся повышенным природным и техногенным геохимическим фоном ртути, а именно: вещества потока рассеяния хвостохранилища Ново-Урского месторождения (п. Урск, Кемеровская область) и твердого осадка снега Курайской ртутной зоны (п. Акташ, Горный Алтай).

Показано, что применение метода ТА-ЭТА-ААС для разделения и идентификации сульфида и селенида ртути возможно при значительных содержаниях обоих соединений в исследуемых образцах, т. е. при сравнительно небольших разбавлениях, однако при этом определение суммы $\mathrm{HgS}$ и $\mathrm{HgSe}$ возможно при любых содержаниях данных форм.

Присутствие обеих форм подтверждается данными СЭМ ЭДС. Показано, что интервалы температурных выходов изучаемых форм ртути $\left(\mathrm{Hg}^{2+}\right.$; смесь $\mathrm{HgS} / \mathrm{HgSe} ; \mathrm{Hg}-\mathrm{OM}$ (форма, связанная с органическим веществом, в том числе $\left.\mathrm{CH}_{3} \mathrm{Hg}^{+}\right)$) в модельных и реальных образцах совпадают. На основании чего можно полагать, что предложенный подход может быть с успехом применен для быстрой и надежной идентификации минералов ртути в гипергенных условиях.
\end{abstract}

Ключевые слова: формы нахождения ртути, ТА-ЭТА-ААС, сканирующая электронная микроскопия, новообразованные минералы ртути.

Цитирование: Густайтис, М.А. Изучение состава минералов Нg в природно-техногенных системах / М. А. Густайтис, И. Н. Мягкая, В. И. Малов, Е. В. Лазарева, О. В. Шуваева // Журн. Сиб. федер. ун-та. Химия, 2021, 14(2). С. $184-196$. DOI: $10.17516 / 1998-2836-0227$ 


\section{Introduction}

Mercury can occur in natural environments as various species that differ in the paths and velocities of migration, bioavailability, and toxicity [1]. On the other hand, stockpiled mining and processing wastes can cause mercury pollution, with formation of secondary dispersion trains superposed over an elevated natural $\mathrm{Hg}$ background [2]. Mercury speciation has been discussed for different kinds of wastes [3], but possible transformations of mercury species in sulfide tailings and their dispersion trains remain less in the focus [4].

Mercury speciesare commonly identified using separation systems (gas and liquid chromatography, capillary electrophoresis, etc.) combined with element detectors (atomic absorption or atomic emission spectroscopy and mass spectrometry). However, these techniques require pre-extraction of mercury compounds to a solution, which may lead to their changes or losses. In this respect, direct determination of compounds $[5,6]$ appears to be a more attractive approach.

Since the mid-1980s, mercury species in natural environment have been analyzed by thermal extraction (sequential evaporation of analytes from solid samples, according to their boiling and melting temperatures) followed by electrothermal AAS detection. The thermal analysis is used also in geological and mineralogical research. In 1978, A. Kolups [7] tried to determine the species of mercury in fluorite from deposits of Central Asia, Kazakhstan, Gorny Altai, and Transbaikalia. The responses of minerals from various ore assemblages to heating were matched against reference thermal curves for Hg compounds, which allowed Kolpus et al. [7] to infer the speciation patterns of mercury in fluorite and related minerals (chlorides, fluorides, nitrates, oxides, sulfates, and sulfides of mercury).

Natural mercury species are either reactive or non-reactive compounds, from which mercury can be reduced to $\mathrm{Hg}^{0}$ in acid or alkaline solutions upon reactions with $\mathrm{SnCl}_{2}$ or $\mathrm{NaBH}_{4}$, respectively. They are, namely, reactive $\mathrm{Hg}^{2+}, \mathrm{HgC}_{2} \mathrm{O}_{4}$, and $\mathrm{HgX}_{2}, \mathrm{HgX}_{3}$, and $\mathrm{HgX}_{4}^{2-}$ (where $\mathrm{X}$ stands for $\mathrm{Cl}^{-}, \mathrm{OH}^{-}$, $\mathrm{Br}$ ), as well as $\mathrm{Hg}^{2+}$ complexes with organic acids, and nonreactive $\mathrm{Hg}(\mathrm{CN})_{2}, \mathrm{HgS}, \mathrm{Hg}^{2+}$ bound with humicsubstances, $\mathrm{CH}_{3} \mathrm{Hg}^{+}, \mathrm{CH}_{3} \mathrm{HgCl}, \mathrm{CH}_{3} \mathrm{HgOH}$, and other Hg-bearing organic compounds. Nonreactive species can become reactive upon digestion in concentrated $\mathrm{HNO}_{3}$ [8]. Note that mercury can also exist in primary opaque minerals (e.g., pyrite and barite), either as isomorphic impurity [9] or as $\mathrm{HgCl}_{2}$ and $\mathrm{Hg}^{0}$ adsorbed on crystal defects.

In 2008 we [10] suggested to analyze mercury species in solid natural samples using thermal release with atomic absorption detection: thermal release analysis combined with electrothermal atomic absorption spectroscopy (TA-ET-AAS). Correspondingly, the curves that record thermal release of mercury species from rocks and minerals can be called desorption curves. The method is applicable to various mercury species: $\mathrm{Hg}$ (II) compounds like $\mathrm{HgCl}_{2}, \mathrm{HgSO}_{4}, \mathrm{Hg}\left(\mathrm{NO}_{3}\right)_{2}$ and $\mathrm{HgO}$; $\mathrm{Hg}$-OM compounds, i.e., mercury bound with organic matter (including methylmercury $\mathrm{CH}_{3} \mathrm{Hg}^{+}$); and mercury sulfide together with mercury selenide $(\mathrm{HgS}+\mathrm{HgSe})$. Thermal analysis turned out to be a workable tool for characterizing the interactions of mercury with the matrix of solid samples $[5,6,10]$. On the other hand, thermal analysis with selective detection of elements may be advantageous as a way of direct $\mathrm{Hg}$ determination in solids.

The method has been tested by separation of model $\mathrm{Hg}$ compounds $\left(\mathrm{HgBr}_{2}, \mathrm{HgCl}_{2}, \mathrm{Hg}_{2} \mathrm{Cl}_{2}, \mathrm{HgS}\right.$ (metacinnabarite and cinnabar), $\mathrm{Hg}_{2} \mathrm{SO}_{4}, \mathrm{HgSO}_{4}, \mathrm{HgO}$ ) $[5,6,10]$ with different user-specified heating rates (e.g., $10{ }^{\circ} \mathrm{C} / \mathrm{min}$ or $1-2{ }^{\circ} \mathrm{C} / \mathrm{s}$ ) and carrier gases (air, nitrogen, or argon) $[5,6,11]$ tailored to the objectives of specific studies or to the instrumental layout. 
Although being advantageous in many respects, the TA-ET-AAS method has some limitations: it requires the presence of tracers, while signals from poorly studied analytes (like $\mathrm{Hg}$ complexes with humic and fulvic acids, adsorbed $\mathrm{Hg}$ species, etc.) can overlap during evaporation [12]. However, the possibility of separate determination of $\mathrm{Hg}$ selenide and $\mathrm{Hg}$ sulfide has never been tested before [5]. Note that both compounds bind $\mathrm{Hg}$ and prevent it from migration and penetration into food chains, sometimes due to natural protective mechanisms, like detoxification by formation of $\mathrm{Hg}$ selenide in the liver of dolphins [13]. Besides the biological systems, mercury selenide often exists in supergene environments [14], sometimes as a secondary phase [15, 16].

The aim of this study is to check whether the TA-ET-AAS method canbe used to analyze the $\mathrm{Hg}$ sulfide and $\mathrm{Hg}$ selenide compounds separately.

\section{Materials and methods}

\section{Samples}

The potentiality of the TA-ET-AAS method in determination of mercury selenide ( $\mathrm{HgSe})$ was tested by matching the results for field samples to those for reference samples made in laboratory according to [17] (Tables 1, 2). First, alaboratory sample originally containing $200 \mathrm{mg} / \mathrm{g} \mathrm{Hg}$ was made from mercury selenide mixed with $\mathrm{Al}_{2} \mathrm{O}_{3}$. Then it was used to fabricate other reference samples with $40,10,2.0,0.4,0.1,0.02,0.004,0.001,0.0002,0.00004$, and $0.00001 \mathrm{mg} / \mathrm{g} \mathrm{Hg}$ by successive dilution with $\mathrm{Al}_{2} \mathrm{O}_{3}$, as recommended in [10]. The reference samples were stored in tightly covered plastic vials.

Four field samples (Table 2) included two samples of debris precipitates from snow (A-5/19 and A-24/19) collected near Aktash Village (Altai region) and two samples from the dispersion train of the Ursk sulfide tailings (Kemerovo region). The Aktash areais known for its popular tourist attractions and, at the same time, for natural and mining-related $\mathrm{Hg}$ anomalies. Sample A-5/19 from the vicinity of the Chuya Hydro Power Station represents the high natural $\mathrm{Hg}$ background of the Kurai mercury zone. The other sample (A-24/19) is from the alluvium of the Yarly-Amry and Chibitka rivers affected by mining-related $\mathrm{Hg}$ loads being located $2.5 \mathrm{~km}$ from the Aktash Processing Plant and its stockpiled wastes [18-20]. The Altai area is traversed by the Chuya motor road, with multiple natural and manmade monuments along the way (North Chuya Range, Kurai steppe, Chuya Hydro, a site of Marsian-like colored mountains, etc.), and the road leading to the North Chuya Range passes through the plant site.

Debris in snow is a mixture of rock fragments, minerals, and plant remnants that are present in the sampled territory. Sample A-5/19 from the Kurai mercury zone consists of quartz, K-feldspar,

Table 1. Parameters of $\mathrm{Hg}$ salts according to empirical TA-ET-AAS data for laboratory-made samples and published evidence, compared

\begin{tabular}{|l|c|c|c|}
\hline \multirow{2}{*}{ Compound } & \multicolumn{2}{|c|}{ Published data } & Our data \\
\cline { 2 - 4 } & $\mathrm{T}_{\mathrm{mlt}},{ }^{\circ} \mathrm{C}$ & $\mathrm{T}_{\mathrm{bl}},{ }^{\circ} \mathrm{C}$ & $\mathrm{T}^{\circ} \mathrm{C}$ Peak (range) \\
\hline $\mathrm{HgCl}_{2}{ }^{*}$ & 276 & 304 & $120(75-150)$ \\
\hline $\mathrm{CH}_{3} \mathrm{HgCl}^{*}$ & 170 & 300, diss & $170(150-220)$ \\
\hline $\mathrm{HgSe}^{* *}$ & 799 & subl & $210(190-270)$ \\
\hline $\mathrm{HgS}^{*}$ & $583, \mathrm{subl}$ & 1450 & $230(220-280)$ \\
\hline
\end{tabular}

Note: *[23]; **[24]; $\mathrm{T}_{\mathrm{mlg}}=$ melting point; $\mathrm{T}_{\mathrm{bl}}=$ boiling point; subl = sublimation; diss = dissociation.

$$
-187-
$$




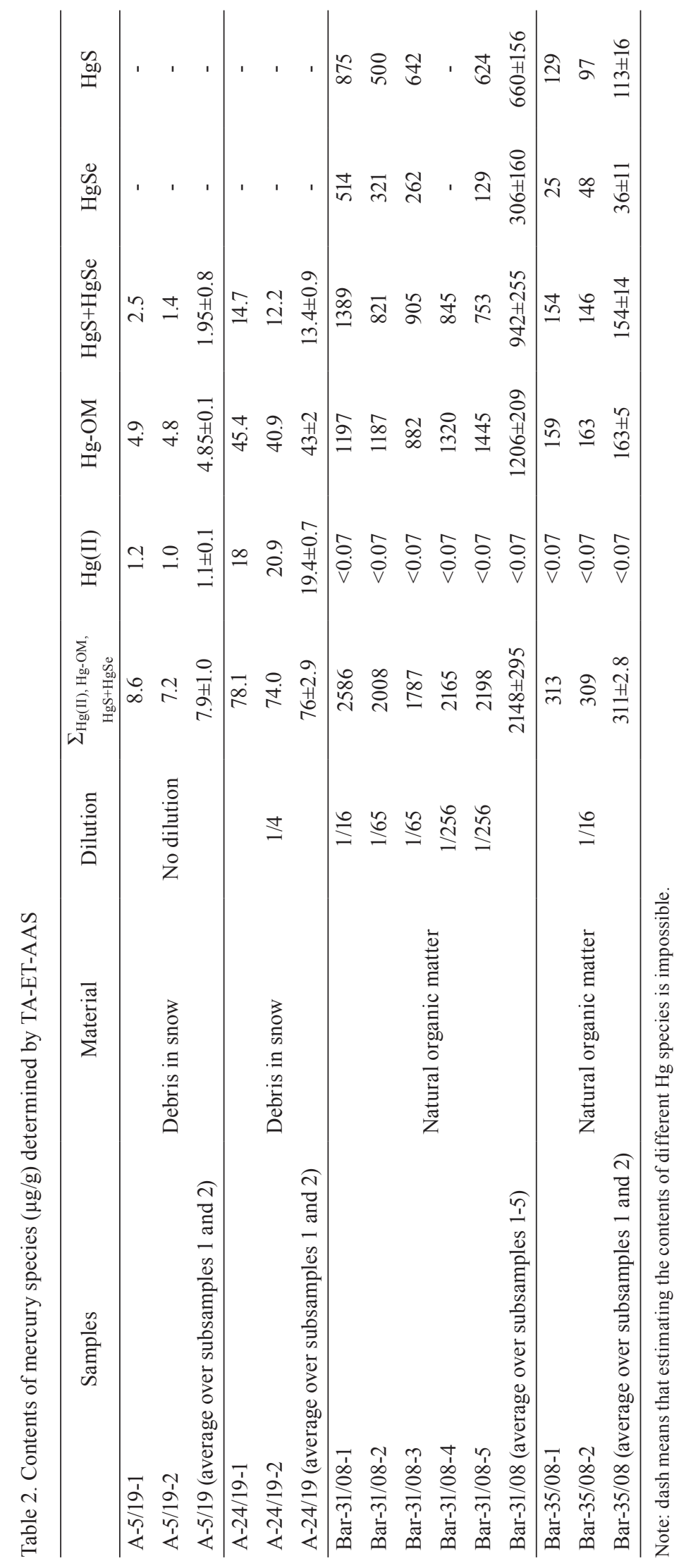


plagioclase, micas, clay, carbonate, and rutile minerals and a minor amount of organic remains. Sample A-24/19 from the Aktash Processing Plant vicinity has similar mineralogy: quartz, K-feldspar, micas, clay, calcite, and dolomite, as well as minor percentages of pyroxenes, plagioclase, apatite, and rutile [19].

Two other samples represent natural organic matter (NOM) from the Ursksite: peat mound material that contacts oxide wastes (Bar-31/08) and natural organic matter buried under wastes (Bar35/08) $[15,16]$. The two samples contain $1848 \mu \mathrm{g} / \mathrm{g} \mathrm{Hg}, 382 \mu \mathrm{g} / \mathrm{g} \mathrm{Se}$, and $33.8 \mu \mathrm{g} / \mathrm{g} \mathrm{I}($ Bar-31/08) and $707 \mu \mathrm{g} / \mathrm{g} \mathrm{Hg}, 163 \mu \mathrm{g} / \mathrm{g} \mathrm{Se}$, and $23.1 \mu \mathrm{g} / \mathrm{g}$ I (Bar-35/08), as determined by X-ray Fluorescence analysis with synchrotron radiation (SR-XRF). The NOM material has interacted for decades with the wastes shed from stock piles and with acid mine drainage (AMD), which led to its high enrichment in $\mathrm{Au}$, $\mathrm{Ag}$, and $\mathrm{Hg}[15,16,21,22]$. Both samples contain organic matter (64.4 and $57.3 \%$ LOI, respectively) and mineral substances of the wastes. Natural organic matter in the two samples has rich and diverse mineralogy: authingenic phases of sulfates (gypsum, jarosite, barite, anglesite), Fe(III) hydroxides, aliuminosilicates, sulfides (framboidal pyrite, $\mathrm{Zn}$ sulfides, including sphalerite group minerals and $\mathrm{Hg}$ sulfide (metacinnabarite)), $\mathrm{Hg}$ selenides (timannite), $\mathrm{Ag}$ iodides (iodargyrite), and $\mathrm{Au}^{0}[15,16]$.

\section{Methods}

The contents of mercury $\mathrm{Hg}(\mathrm{II})$, methylmercury $\left(\mathrm{CH}_{3} \mathrm{Hg}^{+}\right)$, mercury sulfide (HgS), and mercury selenide (HgSe) were determined using the thermal release technique coupled with atomic absorption spectroscopy [10]. The measurements were performed on a Lumex RA $915^{+}$mercury analyzer (St.Petersburg, Russia) with a Zeeman background correction and an RP 91C pyrolysis system equipped with an automatic device for translation of samples in the furnace. The temperature around samples was monitored using a THA $(\mathrm{K})$ thermocouple and a TRM1A-SC2.TP.R meter (Fig. 1).

The responses of mercury species (thermal peaks) formed by selective thermal evaporation of the analyte, its atomization, and detection of atomic Hg. Solid samples were introduced into section I of the furnace atomizer with a dosingunit (Fig. 1b). The samples translated inside the atomizer with the special device (Fig. 1c) heated up progressively to temperatures varying with the doser position in the furnace, $700{ }^{\circ} \mathrm{C}$ the highest, which were monitored by the thermocouple. Mercury vapor was carried from section I to section II, where the samples became destroyed catalytically at $800{ }^{\circ} \mathrm{C}$, and then to the analytical cell (Fig. 1b) by an air flux circulating continuously in the system, at a rate monitored by a flow meter. For measuring bulk Hg, the samples in the dosing unitwere moved to section I and exposed to $700{ }^{\circ} \mathrm{C}$.

Thus, the thermal peaks of each mercury species form in several steps:

- sequential evaporation, with transformation of compounds and complete or partial dissociation in section I;

- transport of the gas phase from section I to section II with an air flux;

- complete atomization of mercury compounds in section II;

- transport of $\mathrm{Hg}$ atoms to the analytical cell, where absorption signals are measured at $253.7 \mathrm{~nm}$.

The analytical signals of mercury species are characterized qualitatively by the position and temperature range of the respective peaks in the thermogram (Fig. 2) and quantitatively by calculated peak areas. The peak positions and temperature ranges differ in different atomized compounds and may 
b)
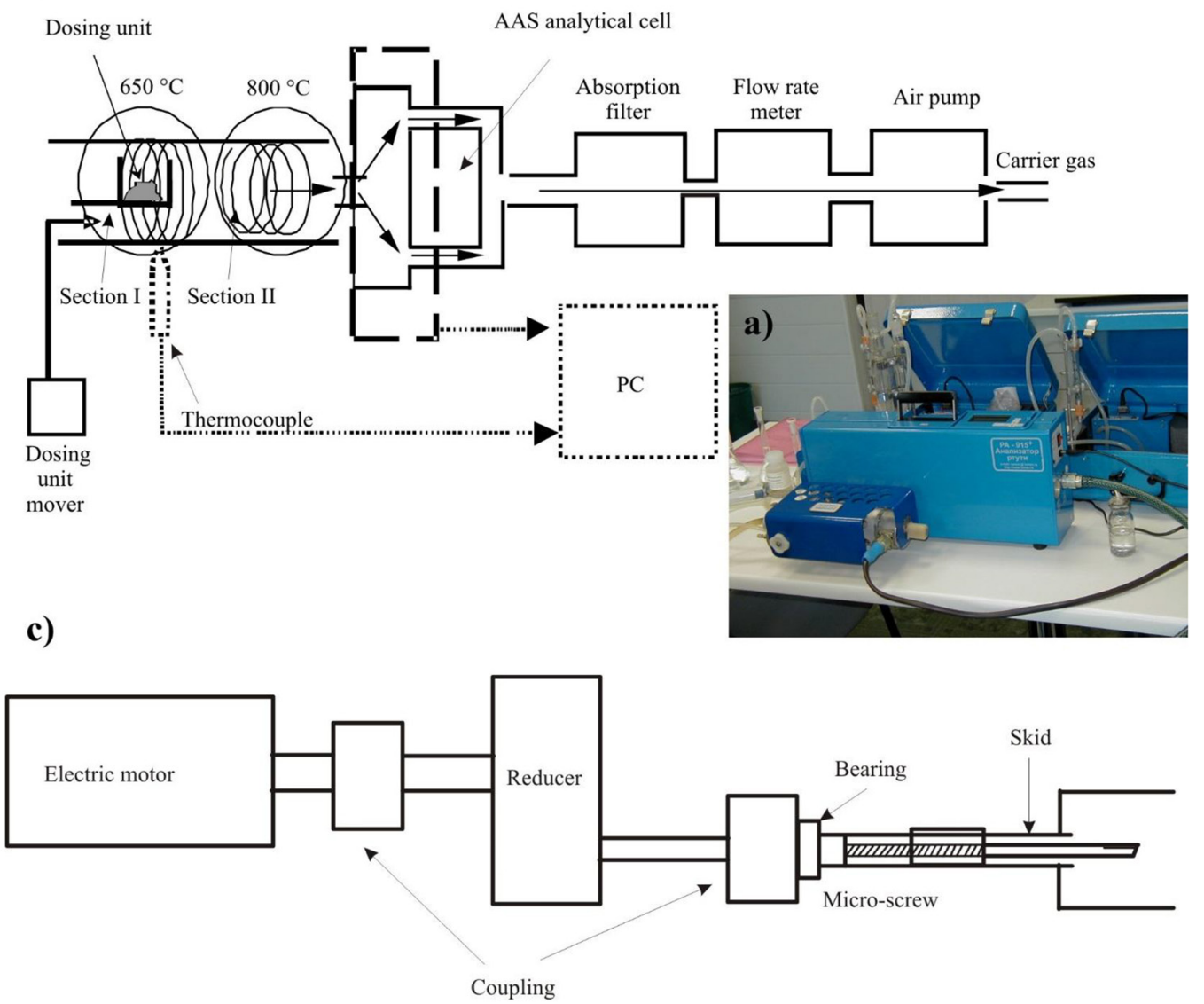

Fig. 1. Instruments used for analyses: a - RA915+ mercury analyzer with an RP91 pyrolysis system (Lumex Ltd., St.-Petersburg); b - sketch of RP91 pyrolysis system. I = section of furnace (atomizer): a quartz tube with a tungsten heater, $t_{\max }=700{ }^{\circ} \mathrm{C}$; II section of catalytical after-burning (atomizer), $t_{\max }=800{ }^{\circ} \mathrm{C}$; $\mathrm{c}-$ dosing unit

depend on the heating rate and, less strongly, on the velocity of the carrier gas; the matrix composition may also play some role.

The presence of $\mathrm{HgS}$ and HgSewas confirmed by scanning electron microscopy on a Tescan MIRA 3 LMU microsope (Czech Republic) with Oxford Instruments INCA Energy 450+ EDS analyzer and an X-MAX 80 silicon drift detector that can resolve $0.02-0.1 \mu \mathrm{m}$ particles. The mineralogy was analyzed in non-preconditioned samples fixed on the stage with a conductive adhesive tape. The operating conditions were: accelerating voltage $20 \mathrm{kV}$; beam current $1.6 \mathrm{nA}$; resolution $1 \mathrm{~nm}$; working distance $15 \mathrm{~mm}$; acquisition time $20 \mathrm{~s}, 60 \mathrm{~s}$, and $150 \mathrm{~s}$ depending on sample complexity.

\section{Results and discussion}

First we analysed the laboratory-made samples (Table 1), which were used for reference in testing the field samples. $\mathrm{Hg}$ (II) salts $\left(\mathrm{HgCl}_{2}\right.$ in this study) dissociated at the lowest temperatures. The samples possibly contained other $\mathrm{Hg}$ (II) compounds (with halides, oxygen, and sulfur), as it was then confirmed by SEM microanalysis $[16,19]$. The $\mathrm{CH}_{3} \mathrm{HgCl}$ species peaked at $170{ }^{\circ} \mathrm{C}$ (Table1), but the peaks of methylmercury and mercury occurring as impurity (or as microinclusions of $\mathrm{Hg}$ phases) 


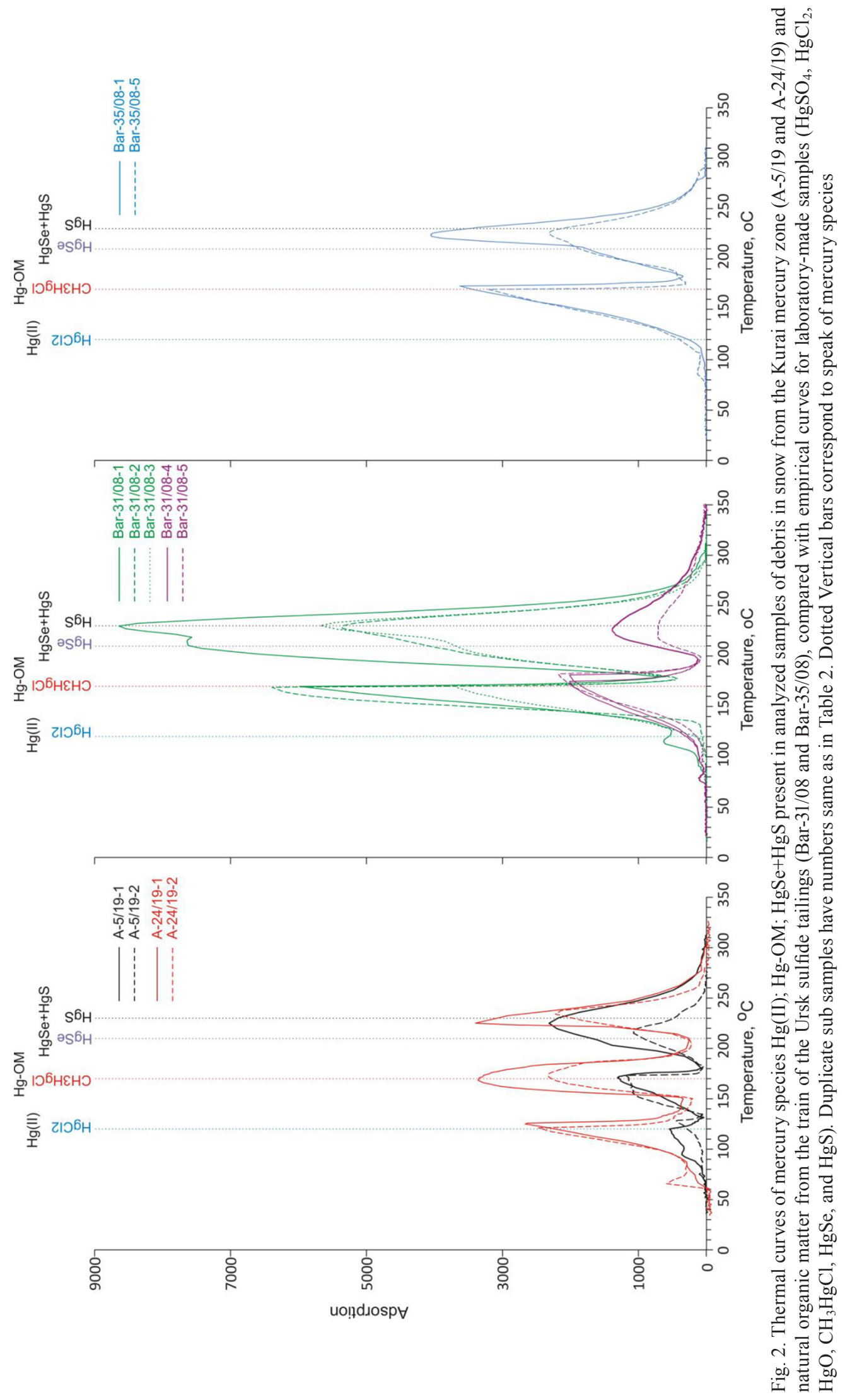


turned out to appear within the same temperature ranges [11]. Thus, the true content of methylmercury in materials where it coexists with primary sulfides from pyritic orescan be estimated as difference between the TA-ET-AAS value and total $\mathrm{Hg}$ in pyrite and barite, with reference to their percentages in the sample [11]. This option was then tested in samples from the dispersion train of the Ursk tailings. The thermal peaks of $\mathrm{Hg}$ selenide and $\mathrm{Hg}$ sulfide appeared at $210{ }^{\circ} \mathrm{C}$ and $230{ }^{\circ} \mathrm{C}$, respectively, with a $20{ }^{\circ} \mathrm{C}$ difference (Table 1), which is sufficient to discriminate between the two compounds.

Then analyses were applied to the field samples (Table 2). The thermal responses of both samples A-5/19 and A-24/19 from natural and mining-affected Altai sites, respectively, include three prominent peaks (Fig. 2). Two duplicate subsamples of A-5/19, which contains $7.9 \mu \mathrm{g} / \mathrm{g} \mathrm{Hg}$ on average, show the first $\mathrm{Hg}$ (II) peaks at slightly different temperatures of $120^{\circ} \mathrm{C}$ and $128^{\circ} \mathrm{C}$ (Fig. 2) though have similar quite low respective $\mathrm{Hg}$ (II) contents of $1.2 \mu \mathrm{g} / \mathrm{gand} 1 \mu \mathrm{g} / \mathrm{g}$ (Table 2). The second peak has slightly different shapes in the two subsamples, though it appears at similar temperatures $\left(171{ }^{\circ} \mathrm{C}\right.$ and $\left.173{ }^{\circ} \mathrm{C}\right)$, and the $\mathrm{Hg}$ (II) contents are nearly identical: $4.9 \mu \mathrm{g} / \mathrm{g}$ and $4.8 \mu \mathrm{g} / \mathrm{g}$ (Fig. 2). The second peak most likely refers to methylmercury because neither pyrite and other sulfides, nor barite were revealed in the sample. The third peak can be considered homogeneous (Fig. 2) though itstemperatures likewise differ in the two subsamples $\left(225^{\circ} \mathrm{C}\right.$ and $\left.215^{\circ} \mathrm{C}\right)$. Note that the curve of A-5/19-1 has a shelf corresponding to HgSe (Fig. 2), but SEM-EDSdata show only cinnabar (Panels 4 and 6 in Fig. 3) and no Hg selenide. Even if HGSe exists, it is yet impossible to discriminatefrom $\mathrm{HgS}$. The $\mathrm{HgS}+\mathrm{HgSe}$ contents in the
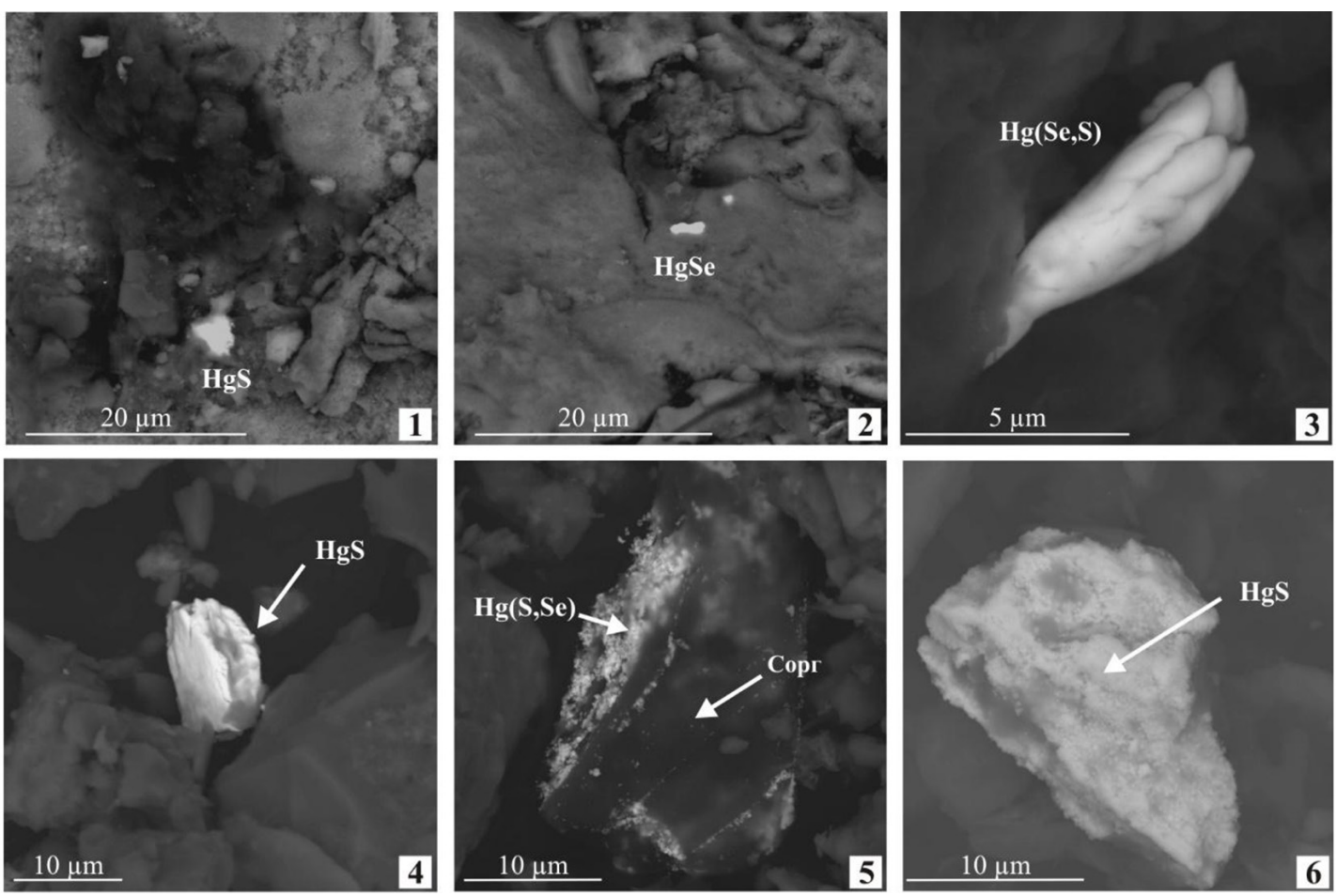

Fig. 3. BSE images of $\mathrm{Hg}$ minerals in samples of NOM from the peat mound surface (1-2); NOM buried under oxide wastes in the train of the Ursk tailings (3) [15]; snow from the vicinity of Aktash Mining and Processing Combine (4-6) [19]: 1 = fine-grained HgS aggregate with Se impurity among iron hydroxides; 2 = HgSe particle among iron hydroxides; 3 = Se-bearing mercury sulfide $(\mathrm{Hg}(\mathrm{Se}, \mathrm{S})) ; 4$ = fragment of mercury sulfide $(\mathrm{HgS})$; 5 = flake-like $\mathrm{Hg}(\mathrm{S}, \mathrm{Se})$ particles coexisting with organic matter $\left(\mathrm{C}_{\mathrm{org}}\right), 6=$ film of secondary $\mathrm{HgS}$ minerals 
two subsamples differ markedly $(2.5 \mu \mathrm{g} / \mathrm{gand} 1.4 \mu \mathrm{g} / \mathrm{g})$, which is reasonable since the contents are low while the amount of mineral chips may be different (Table 2).

The other sample of debris from snow (sample A-24/19) contains $76 \mu \mathrm{g} / \mathrm{g} \mathrm{Hg}$, which is ten times greater than in A-5/19 (Table 1). The peaks appear at slightly different temperatures in the curves of two A-24/19 subsamples: $125^{\circ} \mathrm{C}$ and $121{ }^{\circ} \mathrm{C}$ ( $\mathrm{Hg}(\mathrm{II})$, peak 1); $172{ }^{\circ} \mathrm{C}$ and $175{ }^{\circ} \mathrm{C}$ (Hg-OM, peak 2); 225 and $234{ }^{\circ} \mathrm{C}(\mathrm{HgS}+\mathrm{HgS}$, peak 3). The subsamples contain similar amounts of each $\mathrm{Hg}$ species: $19.4 \mu \mathrm{g} / \mathrm{g} \mathrm{HgII}, 43 \mu \mathrm{g} / \mathrm{g} \mathrm{Hg}-\mathrm{OM}$, and $13.4 \mu \mathrm{g} / \mathrm{g} \mathrm{HgS}+\mathrm{HgS}$ on average (Table 2). The peak corresponding to $\mathrm{HgS}+\mathrm{HgSe}$ is rather homogeneous (Fig. 2). SEM-EDS microanalysis of sample A-24/19 confirms the presence of cinnabar (Panels 4, 6 in Fig. 3), together with complex aggregates of Hg compounds with S and Se in organic remnants (Panel 5 in Fig. 3). The analyzed compounds are known to contain oxygen but it is unclear whether they correspond to the $\mathrm{Hg}$ (II) species in the thermograms and whether they dissociate at the same temperature as $\mathrm{Hg}-\mathrm{OM}$ or have a mixed composition. The presence of $\mathrm{HgSin}$ debris precipitated from snow has been identified reliably and confirmed by SEM-EDS data, while small variations of the $\mathrm{HgS}+\mathrm{HgS}$ peak indicate that the sample contains only cinnabar.

Sample Bar-31/08 collected near the surface in the dispersion train of the Ursk sulfide tailings bears both sulfides and selenides of mercury (Panels 1-3 in Fig. 3), while buried NOM (Bar-35/08) contains mineralogically identified $\mathrm{Hg}$ sulfides with Se only as impurity (6 wt.\%). The secondary $\mathrm{Hg}$ phases have submicrometer to micrometer sizes within $10 \mu \mathrm{m}$.

The TA-ETA-AAS method has resolved only Hg-OM and HgS+HgSe species in NOM (Fig. 2, Table 1). The contents of $\mathrm{Hg}$ in the Ursk NOM samples are much higher than in the Altai debris samples, and reach $2148 \mu \mathrm{g} / \mathrm{g}$ in Bar-31/08, which allowed us to study the peak patterns of $\mathrm{Hg}$ species in several subsamples of Bar-31/08 at different dilution ratios from 1:16 to 1:256.

Sample Bar-31/08 shows two prominent $\mathrm{HgS}+\mathrm{HgSe}$ peaks at 1:16, but the HgSe peak appears as a shelf on the HgS peak (Fig. 2) at greater dilution (Bar-31/08-2 and Bar-31/08-3 subsamples). The HgSe shelf is quite distinct also in the response of Bar-35/08, at 1:16 dilution (Fig. 2).

The peak shapes and temperatures $\left(170^{\circ} \mathrm{C}\right)$ of $\mathrm{Hg}-\mathrm{OM}$ at dilution ratios of 1:16 and 1:65 are similar, but the peak temperatures of subsamples Bar-31/08-4 and Bar-31/08-5 shift to $178{ }^{\circ} \mathrm{C}$ and $175^{\circ} \mathrm{C}$, respectively (Fig. 2). The peak shape of $\mathrm{HgS}+\mathrm{HgSe}$ turned out to be sensitive to dilution: peaks about $212^{\circ} \mathrm{C}$ and $230^{\circ} \mathrm{C}$ in Bar-31/08-1 (1:16) almost exactly correspond to the HgSeand HgSreference (Table 1), but the peaks for Bar-31/08-2 and Bar-31/08-3 (1:65) are more homogeneous, though with a shelf about $210{ }^{\circ} \mathrm{C}$ (Fig. 2). Subsamples Bar-31/08-4 and Bar-31/08-5 obtained by 1:256 dilution yield a unimodal peak, which is quite largein the case of Bar-31/08-5 andrequires additional study. The $\mathrm{Hg}$ sulfide and $\mathrm{Hg}$ selenide species appear also in SEM-EDS data (Panels 1-3 in Fig. 3).

The contents of $\mathrm{HgS}$ and $\mathrm{HgSe}$ can be calculated in samples diluted to 1:16 and 1:65 from their peak areas estimated with respect to the tentative boundary between two undifferentiated peaks drawn along the normal to the peak base: the areas left and right of the normal for the two peaks, respectively [25]. Thus estimated contents of HgSe in the NOM samples are lower than $\mathrm{HgS}$ (Table 2), and the relative contents of the two Hg species differ in subsamples. Similar calculations, though very approximate, for subsample Bar-31/08-5 (Table 2; Fig. 2) likewise show $\mathrm{HgS}$ enrichment over HgSe.

The thermograms and species contents show variations in $\mathrm{Hg}$ speciation depending on dilution ratio: more diluted subsamples have higher $\mathrm{Hg}-\mathrm{OM}$ and lower $\mathrm{HgS}+\mathrm{HgSe}$ (Fig. 2; Table 2). Note that 
additional grinding of the sample material in the course of dilution may cause oxidation of $\mathrm{HgS}$ and $\mathrm{HgSe}$. More clarity on this point can be achieved by large-scale testing in the course of further studies.

Sample Bar-35/08 contains $311 \mu \mathrm{g} / \mathrm{g} \mathrm{Hg}$, as $\mathrm{Hg}-\mathrm{OM}$ and $\mathrm{HgS}+\mathrm{HgSe}$ species (Fig. 2; Table 2). Mercury speciation in this sample was studied only at 1:16 dilution. The Hg-OM peak appears about $170{ }^{\circ} \mathrm{C}$ and has almost identical shapes in the subsamples (Fig. 2). The peaks of $\mathrm{HgS}+\mathrm{HgSe}$ are likewise similar and correspond to $220^{\circ} \mathrm{C}$ and $225^{\circ} \mathrm{C}$ (Fig. 2); the $\mathrm{HgSe}$ species is marked by a shelf at $210{ }^{\circ} \mathrm{C}$ (Fig. 2). The contents of $\mathrm{HgS}$ and $\mathrm{HgSe}$ calculated as above show some variations in different subsamples (Table 1).

Thus, estimating the contents of $\mathrm{HgS}$ and $\mathrm{HgSe}$ species is possible, provided that material contains a sufficient amount of mercury; the peaks can be discriminated if the dilution ratio is chosen appropriately.

\section{Conclusions}

The thermal release analysis coupled with electrothermal atomic absorption spectroscopy (TA-ET-AAS) has been testedby matching the results forfield samples to those for laboratory-made materials. The field samples includednatural organic matter from the area of the Ursk sulfide tailings, Kemerovo region (Bar-31/08 and Bar-35/08) and debris precipitates from snow collected in the Kurai mercury zone, Altai (A-5/19 and A-24/19). The results show that the combined approach is applicable to detection of the $\mathrm{HgS}$ and $\mathrm{HgSe}$ mercury species. Their sum can be determined reliably whereas the two can be discriminated if their contents are large enough and the dilution is moderate. Note that dilution may cause some oxidation of authigenic $\mathrm{HgS}$ and $\mathrm{HgSe}$ phases. The presence of both species is corroborated by SEM-EDS microanalysis. The temperature ranges for the mercury species $\left(\mathrm{Hg}^{2+}\right.$; $\mathrm{HgS}+\mathrm{HgSe}$ mixture; mercury bound with organic matter $(\mathrm{Hg}-\mathrm{OM})$, including $\mathrm{CH}_{3} \mathrm{Hg}^{+}$) vary slightly in different subsamples of field samples as a function of dilution ratio. The exact causes of the variations require further studies though. Thus, the suggested method is a workable tool for fast and reliable detection of $\mathrm{Hg}$ phases in solids, including rocks exposed to supergene alteration.

\section{Acknowledgements}

The field and analytical works were carried out on government assignment to the V.S. Sobolev Geology and Mineralogy (Novosibirsk), at the Analytical Center for Multi-Element and Isotope Studies and at the Analytical Laboratory of the Institute of Inorganic Chemistry (Novosibirsk). Debris precipitates from snow were analyzed under a support of the Russian Science Foundation (Project 1877-10056).

\section{References}

1. Carmona M., Llanos W., Higueras P., Kocman D. Mercury emissions in equilibrium: a novel approach for the quantification of mercury emissions from contaminated soils. Analytical Methods 2013. Vol. 5(11), P. 2793-2801.

2. Rimondi V., Chiarantini L., Lattanzi P., Benvenuti M., Beutel M., Colica A., Costagliola P., Benedetto F., Gabbani G., Gray J.E., Pandeli E., Pattelli G., Paolieri M., Ruggieri G. Metallogeny, exploitation and environmental impact of the Mt. Amiata mercury ore district (Southern Tuscany, Italy). Italian Journal of Geosciences 2015. Vol. 134(2), P. 323-336. 
3. Cheng H., Hu Y. Mercury in municipal solid waste in China and its control: a review. Environmental science \& technology 2012. Vol. 46(2), P. 593-605.

4. Yan J., Wang C., Wang Z., Yang S., Li P. Mercury concentration and speciation in mine wastes in Tongren mercury mining area, southwest China and environmental effects. Applied Geochemistry 2019. Vol. 106. P. 112-119.

5. Windmöller C.C., Silva N.C., Andrade P.H.M., Mendes L.A., do Valle C.M. Use of a direct mercury analyzer for mercury speciation in different matrices without sample preparation. Analytical Methods 2017. Vol. 9(14), P. 2159-2167.

6. Rumayor M., Gallego J.R., Rodríguez-Valdés E., Díaz-Somoano M. An assessment of the environmental fate of mercury species in highly polluted brownfields by means of thermal desorption. Journal of hazardous materials 2017. Vol. 325, P. 1-7.

7. Kolups A.V., Borodin V.A., Korotaev V.V. Species of mercury in fluorite and accompanying minerals from some endogenous deposits. Russian Journal of Geochemistry 1978. No. 5, P. 729-735.

8. Lindqvist O., Rodhe H. Atmospheric mercury - a review. Tellus B 1985. Vol. 37(3), P. 136-159.

9. Ozerova N.A. Mercury and Magmatism-related Metallogeny. Moscow: Nauka 1986. 232 p.

10. Shuvaeva O.V., Gustaytis M.A., Anoshin G.N. Mercury speciation in environmental solid samples using thermal release technique with atomic absorption detection. Analytica chimica acta 2008. Vol. 621(2), P. 148-154.

11. Gustaytis M.A., Shuvaeva O.V., Anoshin G.N. Thermal evaporation coupled with atomic absorption spectroscopy for detection of mercury species in natural and manmade systems: Anoshin G.N. (Ed.), Chemical Analysis in Geology and Geochemistry. Novosibirsk: Geo Publishers 2016. P. 565-580.

12. Saniewska D., Beldowska M. Mercury fractionation in soil and sediment samples using thermos-desorption method. Talanta 2017. Vol. 168, P. 152-161.

13. Lailson-Brito J., Cruz R., Dorneles P.R., Andrade L., de Freitas Azevedo A., Fragoso A.B., Malm O. Mercury-selenium relationships in liver of Guiana dolphin: the possible role of Kupffer cells in the detoxification process by tiemannite formation. PLoS One 2012. Vol. 7(7), P. e42162.

14. Belogub E.V., Ayupova N.R., Krivovichev V.G., Novoselov K.A., Blinov I.A., Charykova M.V. Se minerals in the continental and submarine oxidation zones of the South Urals volcanogenic-hosted massive sulfide deposits: A review. Ore Geology Reviews 2020. Vol. 122, P. 103500.

15. Myagkaya I.N., Lazareva E.V., Gustaytis M. A., Zhmodik S.M. Gold and silver in a system of sulfide tailings. Part 2: Reprecipitation on natural peat. Journal of Geochemical Exploration 2016. Vol. 165 , P. $8-22$.

16. Myagkaya I.N., Lazareva E.V., Zaikovskii V.I., Zhmodik S.M. Interaction of Natural Organic Matter with Acid Mine Drainage: Authigenic Mineralization (Case Study of Ursk Sulfide Tailings, KemerovoRegion, Russia). Journal of Geochemical Exploration 2020. Vol. 211. P. 106456.

17. Roenkov N.D. A method for obtaining metal selenides. Patent SU 1502457A1. Publ. Date 23.08.89.

18. Robertus Yu.V., Puzanov A.V., Lyubimov R.V Features of mercury pollution in the area of the Aktash mining and processing plant (Altai Republic). Geography and Natural Resources 2015. No. 3 P. 48-55.

19. Malov V.I., Gustaytis M.A., Myagkaya I.N., Saryg-ool B.Yu., Surkov O.N., Badmaeva J.O., Lazareva E.V. Mineralogy of dust aerosols in snow near the Aktash mercury deposit (Altai Republic). Metallogeniya Drevnikh I Sovremennykh Okeanov 2020. No. 1, P. 240-244. 
20. Myagkaya I.N., Saryg-ool B.Yu., Gustaytis M.A., Malov V.I., Kirishenko I.S., Surkov O.N., Lazareva E.V. Features of Hg transport in the Yarly-Amry and Chibitka rivers in the vicinities of the Aktash mining and processing plant (Gorny Altai). Geological Evolution of Water-Rock Interaction. Proc. Conf. of the Russian Science Foundation 2020. P. 250-253.

21. Myagkaya I.N., Saryg-oo, B.Yu., Surkov O.N., Zhmodik S.M., Lazareva E.V., Taran O.P. Natural organic matter from the dispersion train of gold sulfide tailings: group composition and fractionation of elements: case study of Ursk Tailings, Kemerovo Region, Siberia. Geochemistry: Exploration, Environment, Analysis 2021. Vol. 21(1). P. geochem 2020-052.

22. Lazareva E.V., Myagkaya I.N., Kirichenko I.S., Gustaytis M.A., Zhmodik S.M. Interaction of natural organic matter with acid mine drainage: In-situ accumulation of elements. Science of the Total Environment 2019. Vol. 660, P. 468-483.

23. Karyakin V.Yu., Angelov I.I. Pure Chemical Substances: A Guide to Preparation of Inorganic Reagents and Samples in Laboratory. Moscow: Chimiya 1974. 300 p.

24. Volkov A.I., Zharsky I.M. A Handbook in Chemistry. Minsk: Covremennaya Shkola 2005. $608 \mathrm{p}$.

25. Tsarev H.I., Tsarev V.I., Katrakov I.B. Gas Chromatography: Manual and Practical Guide for Chemistry Students Specialized in Gas Chromatographic Analytical Methods. Barnaul: Altai University, 2000. 156 p. 